\title{
Periparturient Responses of Multiparous Holstein Cows Fed Different Dietary Phosphorus Concentrations Prepartum
}

\author{
A. B. Peterson, ${ }^{1, \star}{ }^{\star}$ M. W. Orth, ${ }^{1}$ J. P. Goff, ${ }^{2}$ and D. K. Beede ${ }^{1}$ \\ ${ }^{1}$ Department of Animal Science, Michigan State University, East Lansing 48824 \\ ${ }^{2}$ USDA-ARS, National Animal Disease Center, Ames, IA 50010
}

\begin{abstract}
Our objective was to compare the effects of different prepartum dietary phosphorus concentrations on periparturient metabolism and performance. Forty-two late pregnant multiparous Holstein cows were fed 0.21, 0.31 , or $0.44 \% \mathrm{P}$ (dry basis) for 4 wk before expected calving. After parturition, all cows were fed a common lactation diet $(0.40 \% \mathrm{P})$. In the prepartum period, cows fed $0.21 \% \mathrm{P}$ had lower blood serum $\mathrm{P}$ concentrations compared with cows fed 0.31 or $0.44 \%$ P. However, serum $P$ concentrations of all cows were within the normal range ( 4 to $8 \mathrm{mg} / \mathrm{dL}$ ) until the day of calving when average concentrations dropped below $4 \mathrm{mg} / \mathrm{dL}$. From 3 to $14 \mathrm{~d}$ postpartum, serum $\mathrm{P}$ of cows fed $0.21 \% \mathrm{P}$ was greater than that of cows fed 0.31 or $0.44 \%$ P. No cows presented with or were treated for clinical hypophosphatemia in the periparturient period. Total serum $\mathrm{Ca}$ was lower before calving through $2 \mathrm{~d}$ postpartum for cows fed $0.44 \% \mathrm{P}$ compared with those fed 0.21 or $0.31 \%$. Prepartum dietary P treatments did not alter blood osteocalcin, hydroxyproline, and deoxypyridinoline, indicators of bone metabolism, or concentrations of parathyroid hormone or 1,25-dihydroxyvitamin $\mathrm{D}_{3}$. Energycorrected milk yield and milk composition (first $28 \mathrm{~d}$ of lactation) were not affected by prepartum dietary $\mathrm{P}$ concentrations. It is concluded that feeding $0.21 \% \mathrm{P}(34$ $\mathrm{g}$ of $\mathrm{P} /$ cow daily) prepartum is adequate for periparturient multiparous Holstein cows with high metabolic demands and genetic potential for milk production. No adverse effects on periparturient health, dry matter intake, or 28-d lactation performance resulted.
\end{abstract}

(Key words: phosphorus requirement, periparturient cow, serum phosphorus)

Abbreviation key: 1,25(OH) ${ }_{2} \mathbf{D}_{\mathbf{3}}=1,25$-dihydroxyvitamin $\mathrm{D}_{3}, \mathbf{B E B}=$ base excess, $\mathbf{D P D}=$ deoxypyridinoline, $\mathbf{E C D}=$ expected calving date, $\mathbf{E C M}=$ energy-

Received March 3, 2005.

Accepted July 6, 2005.

Corresponding author: David. K. Beede; e-mail: beede@msu.edu.

*Current address: University of Maryland, Dept. Animal and Avian Sciences, College Park, MD 20742. corrected milk, $\mathbf{i C a}=$ ionized calcium, $\mathbf{O C}=$ osteocalcin , OHP = hydroxyproline, $\mathbf{P T H}=$ parathyroid hormone .

\section{INTRODUCTION}

New dietary $P$ requirements and ration recommendations for late-pregnant, nonlactating dairy cows were advanced by NRC (2001). The new recommendations are lower than those of earlier editions (NRC, 1978, 1989). This is largely because of changes in the way the maintenance requirement for $\mathrm{P}$ is estimated and changes in estimations of the absorption coefficients of dietary $\mathrm{P}$. The earlier estimated absorption coefficients were 0.55 (NRC, 1978) and 0.50 (NRC, 1989), regardless of P source. In contrast, NRC (2001) used absorption coefficients for dietary $\mathrm{P}$ of 0.64 for forages and 0.70 for concentrates, and supplemental mineral sources were each assigned a different absorption coefficient. The new total ration $P$ requirement is based on the absorbed $P$ requirement for late-pregnant dairy cows. However, this new requirement has not been evaluated. Few studies have compared the effects of different prepartum dietary $\mathrm{P}$ concentrations on cows during the periparturient period. Two previous reports described the effects of varying prepartum dietary $\mathrm{P}$ concentrations on responses of plasma $\mathrm{P}, \mathrm{Ca}, \mathrm{Mg}$, and vitamin $\mathrm{D}$ metabolites around parturition (Kichura et al., 1982; Barton et al., 1987). The study of Barton et al. (1987) examined dietary $\mathrm{P}$ concentrations that were all well above the estimated requirement. The study of Kichura et al. (1982) used Jersey cows that were limit-fed experimental diets composed of semipurified ingredients. Thus, these studies were not with contemporary Holstein cows with greater metabolic demands and genetic potential for milk production.

Late stages of gestation and early lactation contribute to changes in both $\mathrm{Ca}$ and $\mathrm{P}$ metabolism (Liesegang et al., 2000). Increased bone resorption occurs because of skeletal mineralization of the fetus in late gestation and milk production during early lactation (Brommage and DeLuca, 1985; Fukuda and Iida, 1993). Milk production requires an available supply of $\mathrm{P}$, and bone resorption was estimated to supply 500 to $600 \mathrm{~g}$ of $\mathrm{P}$ during the first few weeks of lactation (Wu et al., 2000). 
A large portion of $\mathrm{P}$ mobilized from bone tissue may be a direct consequence of $\mathrm{Ca}$ mobilization for $\mathrm{Ca}$ homeostasis in early lactation (Horst, 1986; Wu et al., 2000). Three biochemical bone markers have been evaluated in multiparous cows: osteocalcin (OC), a marker of bone formation (Naito et al., 1990; Liesegang et al., 1998, 2000); and deoxypyridinoline (DPD; Liesegang et al., 1998, 2000; Naito et al., 1990) and hydroxyproline (OHP; Goff et al., 1989; van Mosel and Corlett, 1990), both markers of bone resorption. Effects of dietary $\mathrm{P}$ concentrations on plasma OC concentrations were evaluated in sheep (Corlett and Care, 1988; Scott et al., 1994). However, the effects of prepartum dietary $\mathrm{P}$ concentrations on serum OC, OHP, and DPD concentrations around parturition in dairy cows have not been reported and these markers may be useful indicators of changes in bone metabolism.

It is hypothesized that feeding a prepartum ration to supply between 30 and $35 \mathrm{~g}$ of $\mathrm{P} / \mathrm{cow}$ daily for multiparous Holstein cows is sufficient to meet periparturient requirements without adverse effects on metabolism or early lactation performance. Therefore, the objective of this experiment was to compare the effects of different prepartum dietary $\mathrm{P}$ concentrations on periparturient mineral and acid-base status and lactation performance of multiparous Holstein cows.

\section{MATERIALS AND METHODS}

The experiment was conducted under a protocol approved by the Michigan State University All-University Committee on Animal Use and Care.

\section{Cows and Experimental Design}

Forty-two multiparous, pregnant Holstein cows scheduled for dry-off at the Michigan State University Teaching and Research Center were stratified by expected calving date (ECD), blocked by upcoming parity $(2,3$, and $4+)$, and randomly assigned to 1 of 3 prepartum dietary treatments. After dry-off, cows were kept in individual tie-stalls from $60 \mathrm{~d}$ before ECD until parturition was imminent. Then, they were moved to individual maternity pens with drinking cups and their respective experimental ration just before parturition. Cows typically spent less than $12 \mathrm{~h}$ in these pens before being moved to tie-stalls in a barn with other lactating cows.

\section{Treatments and Diets}

Cows were fed the same diet (containing $0.31 \% \mathrm{P}$ ) during the standardization period from 60 to $28 \mathrm{~d}$ before
Table 1. Ingredient and analyzed chemical composition ${ }^{1}$ of prepartum dietary treatments with different $\mathrm{P}$ concentrations (\% of dietary DM).

\begin{tabular}{|c|c|c|c|}
\hline & \multicolumn{3}{|c|}{ Treatment } \\
\hline & $0.21 \% \mathrm{P}$ & $0.31 \% \mathrm{P}$ & $0.44 \% \mathrm{P}$ \\
\hline \multicolumn{4}{|l|}{ Ingredients } \\
\hline Alfalfa silage & 17.5 & 17.5 & 17.5 \\
\hline Corn silage & 27.0 & 27.0 & 27.0 \\
\hline Beet pulp pellets & 27.0 & 27.0 & 27.0 \\
\hline Cornstarch & 9.14 & 9.14 & 9.14 \\
\hline Corn, ground & 9.01 & 9.01 & 9.01 \\
\hline Mineral-vitamin $\operatorname{mix}^{2}$ & 3.28 & 3.28 & 3.28 \\
\hline Supplement ${ }^{3}$ & 2.11 & 2.11 & 2.11 \\
\hline Rice hulls & 1.81 & 1.29 & 0.90 \\
\hline Blood meal & 1.08 & 1.08 & 1.08 \\
\hline Biuret $^{4}$ & 0.86 & 0.86 & 0.86 \\
\hline Urea & 0.77 & 0.65 & 0.52 \\
\hline Ammonium chloride & 0.39 & 0.39 & 0.39 \\
\hline Monoammonium phosphate & 0.00 & 0.52 & 1.03 \\
\hline \multicolumn{4}{|l|}{ Chemical composition } \\
\hline $\mathrm{CP}$ & 15.0 & 15.1 & 14.5 \\
\hline $\mathrm{ADF}$ & 25.3 & 24.9 & 24.8 \\
\hline $\mathrm{NDF}$ & 38.6 & 38.4 & 38.1 \\
\hline $\mathrm{Ca}$ & 0.78 & 0.80 & 0.79 \\
\hline $\mathrm{P}$ & 0.21 & 0.31 & 0.44 \\
\hline $\mathrm{Mg}$ & 0.36 & 0.37 & 0.37 \\
\hline $\mathrm{K}$ & 0.93 & 0.97 & 0.96 \\
\hline $\mathrm{Na}$ & 0.07 & 0.07 & 0.07 \\
\hline $\mathrm{Cl}$ & 0.49 & 0.48 & 0.47 \\
\hline $\mathrm{S}$ & 0.24 & 0.25 & 0.25 \\
\hline $\mathrm{DCAD}^{5}$ & -2.00 & -1.30 & -1.30 \\
\hline $\mathrm{NE}_{\mathrm{L}}{ }^{6}$ & 1.58 & 1.58 & 1.58 \\
\hline
\end{tabular}

${ }^{1}$ Individual ingredients were sampled every other week, dried $\left(60^{\circ} \mathrm{C}\right)$, ground through a $2-\mathrm{mm}$ screen, and made into a composite across the entire prepartum period for analyses.

${ }^{2}$ Composition (DM basis): soybean hulls $=91.4 \%$; magnesium sulfate $=8 \%$; manganese sulfate $=0.14 \%$; zinc sulfate $=0.11 \%$; copper sulfate $=0.06 \%$; Se $0.99 \%=0.06 \%$; cobalt sulfate $=0.001 \%$; ethylenediaminodihydroiodide $(\mathrm{EDDI})=0.001 \%$; vitamin A, 488,000 IU/kg; vitamin $\mathrm{D}_{3}, 71,000 \mathrm{IU} / \mathrm{kg}$; and vitamin $\mathrm{E}, 2490 \mathrm{IU} / \mathrm{kg}$.

${ }^{3}$ Supplement: SoyChlor 16-7, West Central Soy, Ralston, IA.

${ }^{4}$ Biuret, Moorman's Manufacturing Company, Quincy, IL.

${ }^{5} \mathrm{DCAD}=$ Dietary cation-anion difference: $\operatorname{mEq}[(\mathrm{Na}+\mathrm{K})-(\mathrm{Cl}+$ S)]/100 g of dietary DM.

${ }^{6} \mathrm{NE}_{\mathrm{L}}(\mathrm{Mcal} / \mathrm{kg}$ of $\mathrm{DM})=0.0245 \times$ total digestible nutrients $(\%$ of $\mathrm{DM})-0.12$ (NRC, 1989).

ECD (Table 1). From 28 d before ECD to parturition, each cow was fed a different dietary treatment formulated to contain $0.18,0.30$, or $0.42 \% \mathrm{P}$ (DM basis). Based on actual final $\mathrm{P}$ analyses of the diets (described subsequently), the treatments will be designated henceforth as $0.21 \% \mathrm{P}, 0.31 \% \mathrm{P}$, and $0.44 \% \mathrm{P}$ (dry basis), respectively. Treatment $0.31 \% \mathrm{P}$ was the midconcentration of the 3 treatments formulated to supply the dietary requirement $(34 \mathrm{~g} / \mathrm{d}$ ) of a $765-\mathrm{kg}$ cow at $250 \mathrm{~d}$ of gestation consuming $11.4 \mathrm{~kg}$ of DM daily. Treatments $0.21 \% \mathrm{P}$ and $0.44 \% \mathrm{P}$ were intended to be an equal concentration difference $(0.12 \%)$ lesser and greater than that of treatment $0.31 \%$ P. All dietary treatments contained the same concentrations of corn silage, alfalfa silage, beet 
Table 2. Ingredient and chemical composition of diet fed after calving.

\begin{tabular}{lc}
\hline Ingredient & $\begin{array}{l}\text { \% of } \\
\text { dietary DM }\end{array}$ \\
\hline Corn silage & 21.9 \\
Alfalfa silage & 21.5 \\
Corn, high moisture & 13.8 \\
Mineral-vitamin mix & 13.2 \\
Soybean meal & 9.41 \\
Corn distillers grains & 5.92 \\
Protein supplement ${ }^{1}$ & 4.98 \\
Beet pulp pellets & 4.90 \\
Liquid feed & 4.44 \\
Chemical composition & \\
$\mathrm{CP}$ & 18.7 \\
$\mathrm{ADF}$ & 17.1 \\
$\mathrm{NDF}$ & 30.0 \\
$\mathrm{Ca}$ & 0.80 \\
$\mathrm{P}$ & 0.40 \\
$\mathrm{Mg}$ & 0.25 \\
$\mathrm{~K}$ & 1.19 \\
$\mathrm{Na}$ & 0.29 \\
$\mathrm{Cl}$ & 0.41 \\
$\mathrm{~S}$ & 0.21 \\
$\mathrm{NE}{ }_{\mathrm{L}}{ }^{2}$ & 1.67 \\
\hline
\end{tabular}

${ }^{1}$ Composition (DM basis): $\mathrm{CP}=39.6 \%, \mathrm{Ca}=0.94 \%, \mathrm{P}=0.78 \%, \mathrm{Mg}=$ $0.91 \%, \mathrm{~K}=0.58 \%, \mathrm{Na}=0.95 \%, \mathrm{Cl}=0.30 \%, \mathrm{~S}=0.15 \%, \mathrm{Se}=2 \mathrm{mg} /$ $\mathrm{kg}$, vitamin $\mathrm{A}=11,000 \mathrm{IU} / \mathrm{kg}$, vitamin $\mathrm{D}=2,000 \mathrm{IU} / \mathrm{kg}$, vitamin $\mathrm{E}=$ $40 \mathrm{IU} / \mathrm{kg}$.

${ }^{2}$ Composition (DM basis): $\mathrm{TDn}=89.4 \%, \mathrm{NE}_{\mathrm{L}}=1.98 \mathrm{Mcal} / \mathrm{lb}, \mathrm{CP}=$ $30.3 \%, \mathrm{Ca}=0.9 \%, \mathrm{P}=1.2 \%, \mathrm{~K}=3.0 \%, \mathrm{Mg}=0.5 \%$ and microminerals and vitamins.

${ }^{3} \mathrm{NE}_{\mathrm{L}}(\mathrm{Mcal} / \mathrm{kg}$ of $\mathrm{DM})=0.0245 \times$ total digestible nutrients $(\%$ of DM) -0.12 (NRC, 1989).

pulp pellets, cornstarch, ground corn grain, blood meal, biuret, ammonium chloride, and HCl-treated soybean meal (SoyChlor 16-7, West Central Soy, Ralston, IA). Different amounts of monoammonium phosphate $\left[\left(\mathrm{NH}_{4}\right) \mathrm{H}_{2} \mathrm{PO}_{4}\right]$ in treatments $0.31 \% \mathrm{P}$ and $0.44 \% \mathrm{P}$ replaced rice hulls of treatment $0.21 \% \mathrm{P}$ to increase dietary $\mathrm{P}$ concentrations. To keep all diets isonitrogenous, appropriate amounts of urea were removed from treatments $0.31 \% \mathrm{P}$ and $0.44 \% \mathrm{P}$ (Table 1 ). The basal prepar-

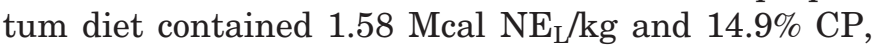
DM basis (Table 1). After parturition, all cows were fed the same lactation diet (1.67 Mcal $\mathrm{NE}_{\mathrm{I}} / \mathrm{kg}$ and $18.7 \%$ CP, DM basis; Table 2).

\section{Feeding and Analyses}

Diets and orts. The experiment lasted from September through February. Cows were fed individually once daily at $0900 \mathrm{~h}$. Orts were weighed once daily at 0800 $\mathrm{h}$ from $60 \mathrm{~d}$ before ECD through 28 DIM to determine daily feed intake. Samples of individual forage and concentrate ingredients were taken every other week, dried in a forced-air oven $\left(60^{\circ} \mathrm{C}\right.$ for $\left.48 \mathrm{~h}\right)$, ground first through a $5-\mathrm{mm}$ screen and then through a $2-\mathrm{mm}$ screen (Thomas-Wiley mill; Thomas Scientific Co., Philadel- phia, PA). After grinding, samples of each feed ingredient were subsampled, blended into a composite, and analyzed for $\mathrm{CP}, \mathrm{NDF}, \mathrm{ADF}$, and mineral elements (Dairy One, Inc., Ithaca, NY).

\section{Collection of Samples, Measurements, and Analyses}

Blood. Blood samples (30 $\mathrm{mL}$ total in three $10-\mathrm{mL}$ syringes) for plasma and serum were collected from the coccygeal vein at $0630 \mathrm{~h}$ on d 28, 25, 22, 19, 16, and 13 before ECD. Samples were taken daily from $10 \mathrm{~d}$ before ECD until parturition. Postpartum samples were taken immediately after calving ( $0 \mathrm{~h}), 6,12,18,24,36,48$, 60 , and $72 \mathrm{~h}$, as well as $4,5,6,7,14,21$, and $28 \mathrm{~d}$ postpartum. Within 30 min after collection, plasma was analyzed using a Stat Profile 4 blood gas and mineral element analyzer (Nova Biomedical, Waltham, MA) to determine $\mathrm{pH}, \mathrm{pCO}_{2}$, hematocrit, and anion gap as well as concentrations of base excess (BEB), $\mathrm{HCO}_{3}^{-}$, ionized $\mathrm{Ca}$ (iCa) normalized to $\mathrm{pH} 7.4, \mathrm{Na}, \mathrm{K}$, and Cl. Concentrations of $\mathrm{P}$ in plasma from individual samples from every sampling time pre- and postpartum were determined in duplicate.

Serum samples were stored at $-10^{\circ} \mathrm{C}$ after centrifugation. Serum OC and DPD concentrations were determined for samples collected $16,3,2$, and $1 \mathrm{~d}$ before calving, immediately after calving $(0 \mathrm{~h})$, and $1,2,3$, and $14 \mathrm{~d}$ after calving. A competitive immunoassay was used to quantify serum OC (Novocalcin; Quidel Corporation, San Diego, CA) and serum DPD (Total DPD; Quidel Corporation). Both assays were validated in our laboratory using bovine blood serum. The interand intraassay variations were calculated using a pooled serum sample analyzed in duplicate in every microplate. The interassay variation was $20.0 \%$ and the intraassay variation was $4.7 \%$ for serum OC, whereas inter- and intraassay variations were 23.6 and $8.1 \%$, respectively, for serum DPD.

Previously selected individual frozen serum samples were sent overnight on dry ice to the USDA National Animal Disease Center Laboratory (Ames, IA) for serum OHP, parathyroid hormone (PTH), and 1,25-dihydroxyvitamin $\mathrm{D}_{3}\left[\mathbf{1 , 2 5}(\mathbf{O H})_{2} \mathbf{D}_{3}\right]$ analyses. Serum OHP concentrations of samples collected on $\mathrm{d} 3,2$, and $1 \mathrm{~d}$ before calving and immediately after calving $(0 \mathrm{~h})$ were determined by colorimetric assay (Daved and Struck, 1971). Serum PTH concentrations of samples collected $5,3,2$, and $1 \mathrm{~d}$ before calving, immediately after calving $(0 \mathrm{~h})$, and $0.5,1,1.5,2,3,4$, and $5 \mathrm{~d}$ after calving were determined using an immunoradiometric assay (Nichols Institute Diagnostics, San Juan Capistrano, CA) previously validated for use with bovine serum (Goff et al., 1989). Serum $1,25(\mathrm{OH})_{2} \mathrm{D}_{3}$ concentrations 
were determined for samples collected $5,3,2$, and $1 \mathrm{~d}$ before calving, immediately after calving $(0 \mathrm{~h})$, and 1 , $2,3,4$, and $5 \mathrm{~d}$ after calving using the radioreceptor assay described by Reinhardt et al. (1984).

Additionally, $125 \mu \mathrm{L}$ of serum from each blood sample collected was deproteinized with $875 \mu \mathrm{L}$ of $20 \%$ TCA and analyzed for total $\mathrm{Ca}, \mathrm{Mg}$, and $\mathrm{P}$ concentrations. Calcium and $\mathrm{Mg}$ concentrations were analyzed by flame atomic absorption spectrometry (Varian SpectrAA 220; Mulgrave, Victoria, Australia) using certified Mg and Ca reference standards (Fisher Scientific, Chicago, IL). Phosphorus concentrations were analyzed in duplicate using a colorimetric assay (Fiske and Subbarow, 1925) adapted for a microplate reader (SpectraMax 190, Sunnyvale, CA). The interassay variation was $5.4 \%$ and the intraassay variation was $1.1 \%$.

$\boldsymbol{B W}$ and BCS. Cows were weighed weekly and assigned BCS (Wildman et al., 1982) from $60 \mathrm{~d}$ before ECD through $28 \mathrm{~d}$ postpartum by 3 independent scorers (blind to experimental treatments). Weekly BCS from all scorers were averaged for each cow before statistical analyses.

Milk. Cows were milked twice daily at 0500 and 1500 h. Milk yield was measured at each milking using a Perfection 3000 Boumatic weigh meter system (Boumatic, Madison, WI) and milk samples were taken by proportional sampler during the morning and afternoon on $\mathrm{d} 7,14,21$, and 28 . Samples from each milking were analyzed separately for fat, true protein, lactose, SNF, and SCC (Michigan DHIA, East Lansing). Daily milk composition was computed based on the relative yields of the morning and afternoon milkings and the respective composition values from samples from each milking. Energy-corrected milk (ECM) was calculated: ECM $(\mathrm{lb})=0.3246 \times$ milk yield $(\mathrm{lb})+12.86 \times$ fat yield $(\mathrm{lb})+$ $7.04 \times$ protein yield (lb) (Dairy Records Management Systems, 1999).

For analysis of $\mathrm{P}$ content of milk, subsamples of milk from morning and afternoon milkings were combined by volume in proportion to milk yield for each milking. Five milliliters of the daily milk composite was placed in a $100-\mathrm{mL}$ volumetric flask and wet-ashed with $4 \mathrm{~mL}$ of sulfuric acid at $440^{\circ} \mathrm{C}$. The samples were evaporated to dryness when the contents of the flasks turned black. To dried samples, $5 \mathrm{~mL}$ of hydrogen peroxide was added slowly drop wise until the solution cleared. This procedure of sequential acid and hydrogen peroxide additions was repeated as needed and samples were completely digested when all black residues disappeared. Digested samples were brought to $100 \mathrm{~mL}$ with deionized distilled water. The $\mathrm{P}$ content of samples was determined by colorimetric method (Fiske and Subbarow, 1925) adapted for a microplate reader (SpectraMax 190, Sun- nyvale, CA). The inter- and intraassay variations were 8.2 and $3.7 \%$, respectively.

\section{Statistical Analyses}

Data were analyzed by least squares ANOVA as a randomized block design with repeated measures using PROC MIXED procedures of SAS (SAS Institute, 1999). The statistical model was:

$$
\begin{gathered}
\mathrm{Y}_{\mathrm{ijkl}=\mu}+\alpha_{\mathrm{i}}+\beta_{\mathrm{j}}+\chi_{\mathrm{k}}+D_{\mathrm{l}(\mathrm{ij})}+(\alpha \beta)_{\mathrm{ij}}+(\beta \chi)_{\mathrm{jk}} \\
+(\alpha \chi)_{\mathrm{ik}}+(\alpha \beta \chi)_{\mathrm{ijk}}+\varepsilon_{\mathrm{ijk}}
\end{gathered}
$$

where $\mu$ = overall mean; $\alpha_{\mathrm{i}}=$ fixed effect of treatment; $\beta_{\mathrm{j}}=$ fixed effect of parity; $\chi_{\mathrm{k}}=$ fixed effect of time; $D_{1(\mathrm{ij})}=$ random effect of cow within the ith treatment and jth parity; $(\alpha \beta)_{\mathrm{ij}}=$ interaction between the ith treatment and jth parity; $(\beta \chi)_{\mathrm{jk}}=$ interaction between the $\mathrm{jth}$ parity and kth time; $(\alpha \chi)_{\text {ik }}=$ interaction between the ith treatment and kth time, $(\alpha \beta \chi)_{\mathrm{ijk}}=$ interaction among the ith treatment; jth parity and kth time; and $\varepsilon_{\mathrm{ijkl}}=$ random error.

Separate ANOVA were conducted with data of relevant dependent variables in the prepartum period (28 $\mathrm{d}$ to $1 \mathrm{~d}$ before ECD), the periparturient period ( $7 \mathrm{~d}$ before through $7 \mathrm{~d}$ after calving), and the postpartum period ( 1 through $28 \mathrm{~d}$ after calving). Results are presented as least squares means. Differences among means were declared at $P<0.05$, and trends were noted $(0.05<P<0.10)$. The effects of treatments (treatment $0.21 \% \mathrm{P}$ vs. treatment $0.31 \% \mathrm{P}$ and treatment $0.44 \% \mathrm{P}$; and treatment $0.31 \% \mathrm{P}$ vs. treatment $0.44 \% \mathrm{P}$ ), time (day or hour depending upon dependent variable), and treatment by day interactions were compared using orthogonal contrasts.

\section{RESULTS AND DISCUSSION}

\section{Standardization Period}

Least squares means of pre-experiment responses of cows measured on d 35 and 42 (both single time points used in statistical analyses) before ECD are presented in Table 3. During the standardization period, all cows were fed dietary treatment $0.31 \% \mathrm{P}$. There was a tendency for greater DMI of cows to be assigned subsequently to treatment $0.21 \% \mathrm{P}$ compared with cows in treatment $0.31 \% \mathrm{P}$ and $0.44 \% \mathrm{P}(P=0.06)$; however, $\mathrm{DMI}$ as a percentage of BW was not different among cows in different treatment groups. Cows to be assigned subsequently to treatment $0.21 \% \mathrm{P}$ had a lower BCS before the start of the experiment than cows in treatment $0.31 \% \mathrm{P}$ and $0.44 \% \mathrm{P}(P<0.01)$. No differences in blood serum or plasma measurements were detected among 
Table 3. Least squares means and orthogonal contrasts by prepartum dietary treatment assignment for variables of the pre-experiment standardization period. ${ }^{1}$

\begin{tabular}{|c|c|c|c|c|c|c|}
\hline \multirow[b]{3}{*}{ Variable } & \multirow{2}{*}{\multicolumn{3}{|c|}{ Treatments }} & \multirow[b]{3}{*}{$\mathrm{SE}$} & \multicolumn{2}{|c|}{ Contrasts } \\
\hline & & & & & \multirow{2}{*}{$\begin{array}{l}0.21 \% \mathrm{P} \text { vs. } \\
0.31 \% \mathrm{P} \\
0.44 \% \mathrm{P}\end{array}$} & \multirow{2}{*}{$\begin{array}{l}0.31 \% \mathrm{P} \text { vs } \\
0.44 \% \mathrm{P}\end{array}$} \\
\hline & $0.21 \% \mathrm{P}$ & $0.31 \% \mathrm{P}$ & $0.44 \% \mathrm{P}$ & & & \\
\hline & & & & & . & - \\
\hline DMI, kg/d & 17.8 & 16.5 & 15.9 & 0.65 & 0.06 & $\mathrm{NS}^{2}$ \\
\hline DMI, \% BW & 2.17 & 2.21 & 2.11 & 0.12 & NS & NS \\
\hline $\mathrm{BCS}$ & 3.21 & 3.63 & 3.60 & 0.09 & 0.01 & 0.01 \\
\hline $\mathrm{BW}, \mathrm{kg}$ & 729 & 721 & 753 & 14.6 & NS & NS \\
\hline \multicolumn{7}{|l|}{ Serum variables } \\
\hline Serum $\mathrm{P}, \mathrm{mg} / \mathrm{dL}$ & 6.50 & 6.74 & 6.66 & 0.41 & NS & NS \\
\hline Serum Ca, mg/dL & 9.87 & 9.40 & 9.51 & 0.37 & NS & NS \\
\hline Serum $\mathrm{Mg}, \mathrm{mg} / \mathrm{dL}$ & 1.89 & 1.81 & 1.89 & 0.08 & NS & NS \\
\hline \multicolumn{7}{|l|}{ Plasma variables } \\
\hline Ionized $\mathrm{Ca}, \mathrm{mg} / \mathrm{dL}$ & 5.53 & 5.35 & 5.52 & 0.08 & NS & NS \\
\hline $\mathrm{Na}, \mathrm{mg} / \mathrm{L}$ & 3306 & 3300 & 3301 & 9.99 & NS & NS \\
\hline $\mathrm{K}, \mathrm{mg} / \mathrm{L}$ & 174 & 179 & 172 & 2.43 & NS & NS \\
\hline $\mathrm{Cl}, \mathrm{mg} / \mathrm{L}$ & 3661 & 3655 & 3648 & 19.8 & NS & NS \\
\hline $\mathrm{pH}$ & 7.41 & 7.42 & 7.42 & 0.01 & NS & NS \\
\hline $\mathrm{BEB},{ }^{3} \mathrm{mmol} / \mathrm{L}$ & 3.29 & 3.12 & 3.13 & 0.42 & NS & NS \\
\hline $\mathrm{pCO}_{2}, \mathrm{mmHg}$ & 43.8 & 41.2 & 42.5 & 1.59 & NS & NS \\
\hline $\mathrm{HCO}_{3}, \mathrm{mmol} / \mathrm{L}$ & 27.8 & 27.0 & 27.6 & 0.77 & NS & NS \\
\hline Anion gap, $\mathrm{m} M$ & 17.1 & 18.2 & 17.4 & 0.55 & NS & NS \\
\hline Hematocrit, \% & 30.4 & 33.8 & 30.6 & 2.12 & NS & NS \\
\hline
\end{tabular}

${ }^{1}$ The means and SE for all variables are from measurements at 2 single time points (d 35 and d 42).

${ }^{2} \mathrm{NS}=$ Not significant $(P>0.10)$.

${ }^{3} \mathrm{BEB}=$ Base excess.

cows to be assigned to the 3 experimental dietary treatments beginning $28 \mathrm{~d}$ before ECD (Table 3 ).

\section{Prepartum Period Responses}

Diet composition, intake, BCS, and BW. Actual average days before parturition when dietary treatments were fed were 28,30 and $28 \mathrm{~d}$ for treatments $0.21 \% \mathrm{P}, 0.31 \% \mathrm{P}$, and $0.44 \% \mathrm{P}$, respectively $(\mathrm{SEM}=2.4)$. Analyzed chemical compositions of the 3 prepartum dietary treatments did not differ except for $\mathrm{P}$ concentrations (Table 1). Average analyzed $\mathrm{P}$ concentrations based on dietary ingredient samples taken throughout the experiment were $0.21,0.31$, and $0.44 \%$ (DM basis) for treatments $0.21 \% \mathrm{P}, 0.31 \% \mathrm{P}$, and $0.44 \% \mathrm{P}$, respectively, which was numerically slightly greater than the formulated concentrations of $0.18,0.30$, and $0.42 \% \mathrm{P}$. For all cows, average DMI during the prepartum period was $15.5 \pm 0.7 \mathrm{~kg} / \mathrm{cow}$ per d and DMI was not affected by dietary treatment (Table 4). This result is different from that of Valk and Sebek (1999), in which DMI was less when cows were fed $0.24 \%$ compared with 0.28 or $0.34 \%$ dietary $\mathrm{P}$ during the dry period. Overall, average daily DMI of cows in the current experiment was considerably greater than predicted by the NRC (2001) model (prediction $=11.4 \mathrm{~kg} / \mathrm{cow}$ ). This may have been due, at least partially, to the relatively high concentrations of beet pulp pellets and cornstarch in the basal diet (36\% of total dietary DM) allowing for greater than predicted intake.

Figure 1 illustrates average daily DMI from $28 \mathrm{~d}$ before calving through $28 \mathrm{~d}$ into lactation, and Figure 2 shows average daily $\mathrm{P}$ intake within each treatment during the prepartum period. Because of greater than predicted DMI, $P$ intakes ( $\mathrm{g} / \mathrm{d}$ ) were greater than originally predicted (Table 4 and Figure 2). Average daily $\mathrm{P}$ intake was 34,48 , and $67 \mathrm{~g} / \mathrm{cow}(\mathrm{SEM}=2.0)$ for cows fed treatments $0.21 \% \mathrm{P}, 0.31 \% \mathrm{P}$, and $0.44 \% \mathrm{P}$, respectively, and differed among dietary treatments $(P<0.01)$. Therefore, actual average $P$ intakes of cows in treatment $0.21 \% \mathrm{P}$, not treatment $0.31 \% \mathrm{P}$ as originally designed, were nearest the $\mathrm{P}$ intake to meet predicted requirement (NRC, 2001) for late pregnant Holstein cows.

There was a tendency for cows in treatment $0.21 \% \mathrm{P}$ to have lower BCS compared with cows in treatments $0.31 \% \mathrm{P}$ and $0.44 \% \mathrm{P}(P=0.08)$. However, change in BCS during the 28-d prepartum period was not affected by treatment. Additionally, there were no differences in BW or change in BW during the $28 \mathrm{~d}$ before calving due to dietary treatment. Wu et al. (2000) and Wu and Satter (2000) similarly found no effects of varying dietary $\mathrm{P}$ treatments over an entire lactation on BCS or BW. 
Table 4. Least squares means and orthogonal contrasts for treatment and treatment by time interactions for animal performance and blood variables during the prepartum period ( 28 through $1 \mathrm{~d}$ prepartum).

\begin{tabular}{|c|c|c|c|c|c|c|c|c|}
\hline \multirow[b]{2}{*}{ Variable } & & & & \multirow[b]{2}{*}{$\mathrm{SE}$} & \multicolumn{2}{|c|}{ Contrasts } & \multicolumn{2}{|c|}{ Contrasts by time ${ }^{1}$} \\
\hline & $0.21 \% \mathrm{P}$ & $0.31 \% \mathrm{P}$ & $0.44 \% \mathrm{P}$ & & $\begin{array}{l}0.21 \% \mathrm{P} \text { vs. } \\
0.31 \% \mathrm{P} \\
0.44 \% \mathrm{P}\end{array}$ & $\begin{array}{l}0.31 \% \mathrm{P} \text { vs. } \\
0.44 \% \mathrm{P}\end{array}$ & $\begin{array}{l}0.21 \% \mathrm{P} \text { vs. } \\
0.31 \% \mathrm{P} \\
0.44 \% \mathrm{P}\end{array}$ & $\begin{array}{l}0.31 \% \mathrm{P} \text { vs. } \\
0.44 \% \mathrm{P}\end{array}$ \\
\hline & & & & & & & 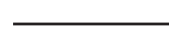 & \\
\hline DMI, kg/d & 16.0 & 15.4 & 15.2 & 0.70 & $\mathrm{NS}^{2}$ & NS & NS & NS \\
\hline DMI, \% BW & 2.07 & 2.08 & 2.01 & 0.09 & NS & NS & NS & NS \\
\hline BCS change & +0.20 & +0.05 & +0.07 & 0.11 & NS & NS & NS & NS \\
\hline $\mathrm{BW}, \mathrm{kg}$ & 756 & 750 & 785 & 16.6 & NS & NS & NS & NS \\
\hline BW change, kg & +25.1 & +22.3 & +26.4 & 4.56 & NS & NS & NS & NS \\
\hline \multicolumn{9}{|l|}{ Serum minerals } \\
\hline Serum $P, \mathrm{mg} / \mathrm{dL}$ & 5.06 & 6.41 & 6.60 & 0.24 & 0.01 & 0.01 & NS & NS \\
\hline Serum Ca, mg/dL & 9.18 & 9.35 & 9.04 & 0.32 & NS & NS & 0.05 & NS \\
\hline Serum Mg, mg/dL & 1.88 & 1.88 & 1.93 & 0.05 & NS & NS & 0.10 & NS \\
\hline $\mathrm{pH}$ & 7.44 & 7.43 & 7.44 & 0.01 & NS & 0.09 & 0.05 & NS \\
\hline $\mathrm{BEB},{ }^{3} \mathrm{mmol} / \mathrm{L}$ & 4.07 & 4.75 & 3.67 & 0.42 & NS & NS & NS & NS \\
\hline $\mathrm{pCO}_{2}, \mathrm{mmHg}$ & 41.0 & 43.7 & 41.0 & 0.99 & NS & 0.07 & NS & NS \\
\hline $\mathrm{HCO}_{3}, \mathrm{mmol} / \mathrm{L}$ & 27.8 & 28.8 & 27.5 & 0.49 & NS & NS & NS & 0.06 \\
\hline Anion gap, $\mathrm{m} M$ & 16.7 & 17.7 & 17.6 & 0.27 & 0.02 & NS & NS & NS \\
\hline \multicolumn{9}{|l|}{ Serum bone markers ${ }^{4}$} \\
\hline Serum OC, ng/mL & 22.3 & 28.8 & 27.4 & 2.44 & 0.06 & 0.07 & NS & 0.02 \\
\hline Serum DPD, ng/mL & 2.57 & 2.73 & 2.75 & 0.21 & NS & NS & NS & NS \\
\hline Serum OHP, $\mu \mathrm{g} / \mathrm{mL}$ & 1.98 & 1.98 & 2.12 & 0.13 & NS & NS & NS & NS \\
\hline
\end{tabular}

${ }^{1}$ Interaction of treatment with time from 28 to $1 \mathrm{~d}$ before calving.

${ }^{2} \mathrm{NS}=$ Not significant $(P>0.10)$.

${ }^{3} \mathrm{BEB}=$ Base excess.

${ }^{4} \mathrm{OC}=$ Osteocalcin; DPD = deoxypyridinoline; OHP = hydroxyproline.

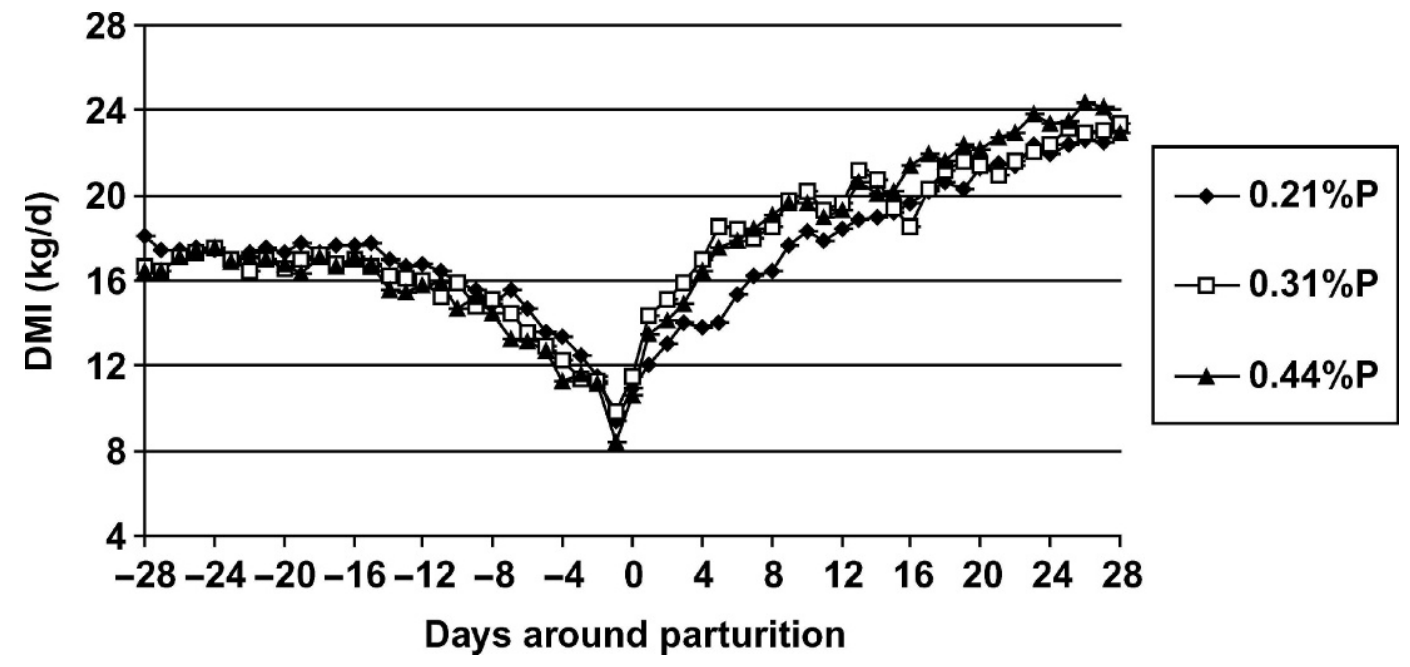

Figure 1. Dry matter intake as affected by prepartum dietary $\mathrm{P}$ treatments $(0.21,0.31$, or $0.44 \%$ dietary $\mathrm{P}$, dry basis) from $28 \mathrm{~d}$ prepartum through $28 \mathrm{~d}$ postpartum; $\mathrm{d} 0$ is day of calving (SEM $=1.2$ ). 


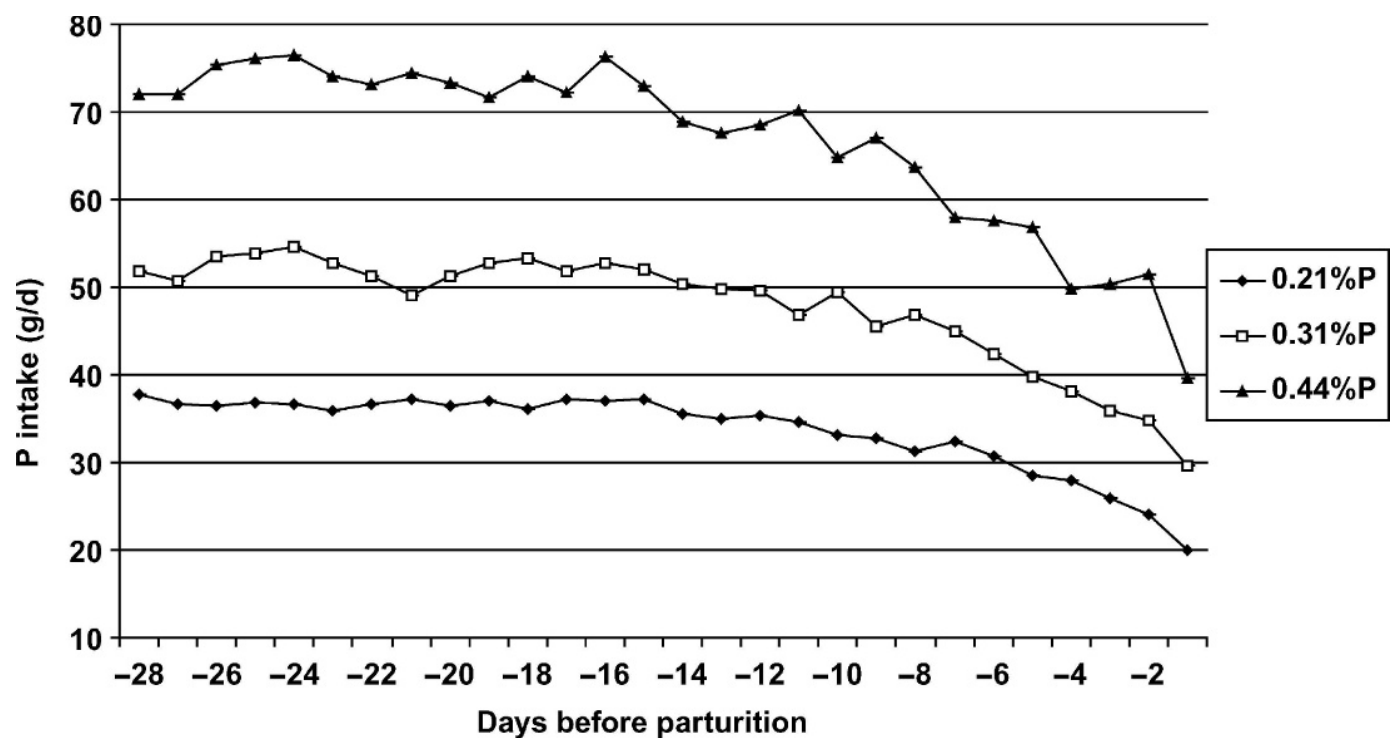

Figure 2. Effect of prepartum dietary $\mathrm{P}$ treatments $(0.21,0.31$, or $0.44 \%$ dietary $\mathrm{P}, \mathrm{DM}$ basis $)$ on $\mathrm{P}$ intake during the $28 \mathrm{~d}$ before parturition ( $\mathrm{SEM}=3.0 ; P<0.02$ for treatment by time interaction).

Serum P, Ca, and Mg. Prepartum serum P concentrations were less for cows in treatment $0.21 \% \mathrm{P}$ compared with the average of cows in treatments $0.31 \% \mathrm{P}$ and $0.44 \% \mathrm{P}(P<0.01 ;$ Table 4$)$. The average prepartum serum $\mathrm{P}$ concentration $(5.06 \mathrm{mg} / \mathrm{dL})$ for cows fed $0.21 \%$ $\mathrm{P}$ was within the normal range (4 to $8 \mathrm{mg} / \mathrm{dL}$ ) for adult ruminants (Goff, 1998). Additionally, cows in treatment $0.31 \% \mathrm{P}$ had lesser serum $\mathrm{P}$ concentrations than cows in treatment $0.44 \% \mathrm{P}(P<0.01$; Table 4$)$. These results are similar to those of Kichura et al. (1982) in which Jersey cows fed $10 \mathrm{~g}$ of $\mathrm{P} /$ head daily had lower plasma $\mathrm{P}$ concentrations than those fed $80 \mathrm{~g}$ of $\mathrm{P} /$ head daily from 4 wk prepartum until parturition. Barton et al. (1987) reported that cows (per treatment $=5$ Holsteins, 2 Ayrshires, 2 Guernseys, and 1 Jersey) fed 0.7 times maintenance requirement (NRC, 1978) for P prepartum had lower prepartum plasma $\mathrm{P}$ concentrations than cows fed at either 1 or 3 times the maintenance requirement for dietary P. Figure 3 shows serum P concentrations of cows in each prepartum dietary treatment from $28 \mathrm{~d}$ before through $28 \mathrm{~d}$ after calving. There was no dietary treatment by time interaction during the prepartum period on serum $\mathrm{P}$ concentrations $(P>0.05)$.

Varying prepartum dietary $\mathrm{P}$ concentration did not alter prepartum total serum Ca concentrations pooled across time $(P>0.10$; Table 4 , Figure 4$)$. Barton et al. (1987) also reported no change in average prepartum plasma Ca concentrations when cows were fed $0.7,1$, or 3 times maintenance requirement for dietary P (NRC, 1978). Similarly, Kichura et al. (1982) reported no change in prepartum plasma $\mathrm{Ca}$ concentrations when Jersey cows were fed either 10 or $80 \mathrm{~g}$ of P/cow daily.
In the current experiment, there was an interaction of prepartum dietary $\mathrm{P}$ treatment by day on total serum $\mathrm{Ca}$ indicating that response across days prepartum was dissimilar among treatment groups $(P<0.05 ; 0.21 \% \mathrm{P}$ vs. $0.31 \% \mathrm{P}, 0.44 \% \mathrm{P}$ by day; Figure 4 ). Prepartum serum $\mathrm{Mg}$ concentrations averaged $1.89 \pm 0.05 \mathrm{mg} / \mathrm{dL}$ and were not altered by prepartum dietary treatment $(P>0.10$; Table 4). These results are similar to those of Barton et al. (1987) in which varying prepartum dietary $\mathrm{P}$ had no effect on prepartum plasma $\mathrm{Mg}$ concentrations.

Plasma mineral elements and acid-base variables. Plasma iCa was not altered by treatment $(P>$ 0.10 ; Table 4). However, there was a treatment by day interaction for plasma iCa (Figure 5; $P<0.01$ ). Temporal patterns of $\mathrm{iCa}$ around parturition were similar to those observed by Rodriguez-Suarez (1998) from $10 \mathrm{~d}$ prepartum until parturition when prepartum dietary Ca varied. The effects of prepartum dietary $\mathrm{P}$ content on plasma $\mathrm{Na}(P=0.03), \mathrm{K}(P>0.10)$, and $\mathrm{Cl}(P>0.10)$ concentrations were numerically very small (Table 4 ).

There were no significant differences in plasma $\mathrm{pH}$, $\mathrm{BEB}, \mathrm{pCO}_{2}, \mathrm{HCO}_{3}$, and hematocrit due to prepartum dietary $\mathrm{P}$ concentration (Table 4). Plasma anion gap in the prepartum period was less for cows in treatment $0.21 \% \mathrm{P}$ compared with those in treatments $0.31 \% \mathrm{P}$ and $0.44 \% \mathrm{P}(P=0.02)$.

$O C, D P D$, and $O H P$. The serum OC concentration of cows in treatment $0.21 \% \mathrm{P}$ tended to be less than that of cows in treatments $0.31 \% \mathrm{P}$ and $0.44 \% \mathrm{P}$ in the prepartum period $(P=0.06$; Table 4$)$. These results suggest, considering $\mathrm{OC}$ as a marker of osteoblastic activity, that feeding $0.21 \% \mathrm{P}$ during the prepartum 


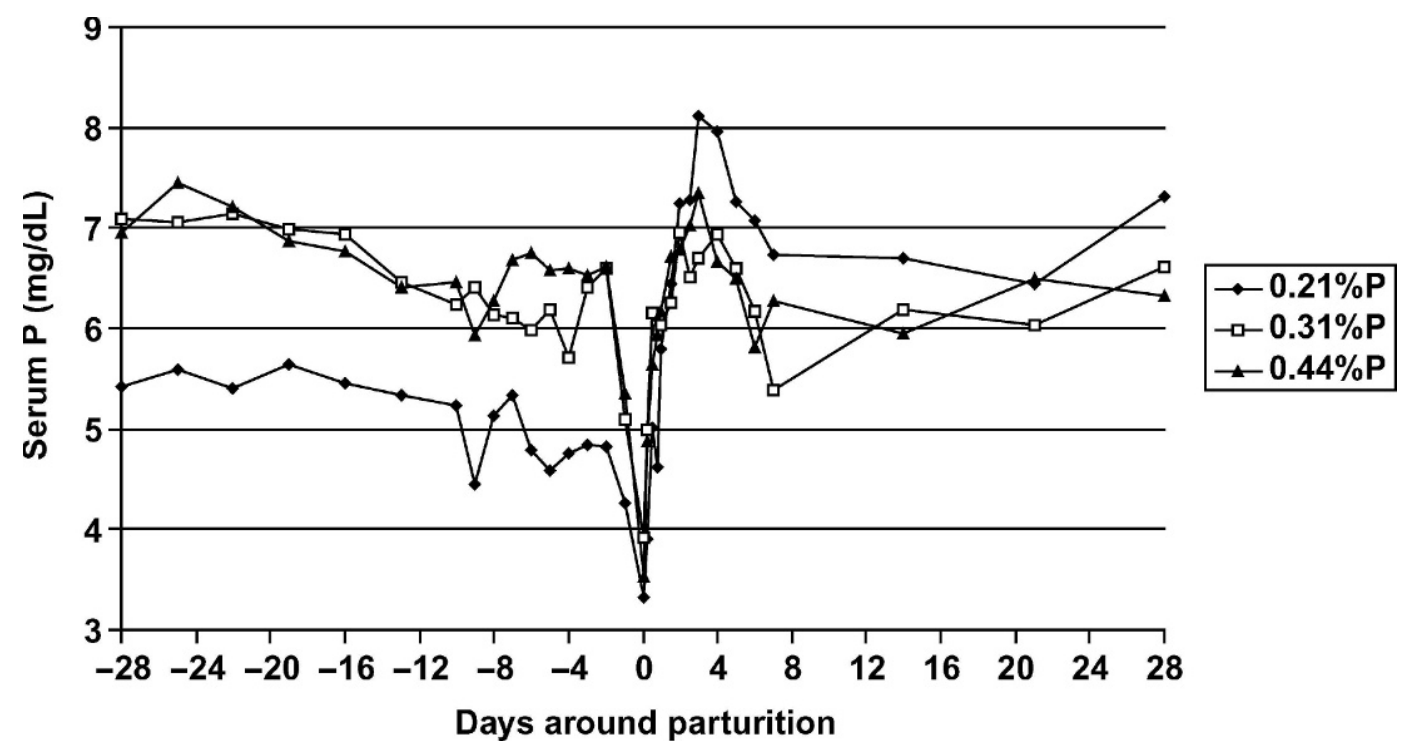

Figure 3. Effects of prepartum dietary $\mathrm{P}$ treatments $(0.21,0.31$, or $0.44 \%$ dietary $\mathrm{P}$, dry basis $)$ on serum $\mathrm{P}$ concentrations from $28 \mathrm{~d}$ prepartum through $28 \mathrm{~d}$ postpartum; $\mathrm{d} 0$ is day of calving ( $\mathrm{SEM}=0.38 ; P<0.01$ for treatment by time interaction in the periparturient and postpartum periods).

period may reduce bone formation, perhaps to aid in maintenance of normal blood concentrations of $\mathrm{P}$ and Ca as parturition approaches. Corlett and Care (1988) and Scott et al. (1994) reported that lower dietary $\mathrm{P}$ concentration reduced serum OC concentrations in sheep. Naito et al. (1990) characterized temporal patterns of prepartum plasma OC concentrations of multiparous Holstein cows and found that plasma OC concentrations decreased from $22 \mathrm{ng} / \mathrm{mL}$ at $5 \mathrm{~d}$ prepartum to $16 \mathrm{ng} / \mathrm{mL}$ at parturition. A similar decline from $\mathrm{d} 16$, 3,2 , and $1 \mathrm{~d}$ before calving to parturition was observed in the current experiment.

There was no effect of dietary treatment on prepartum serum DPD concentrations (overall mean $=2.68 \pm$ $0.21 \mathrm{ng} / \mathrm{mL}$; Table 4$)$. No comparable results were found in the literature assessing patterns of serum DPD concentrations as an indicator of bone resorption in dairy cows. However, Scott et al. (1994) reported that neither

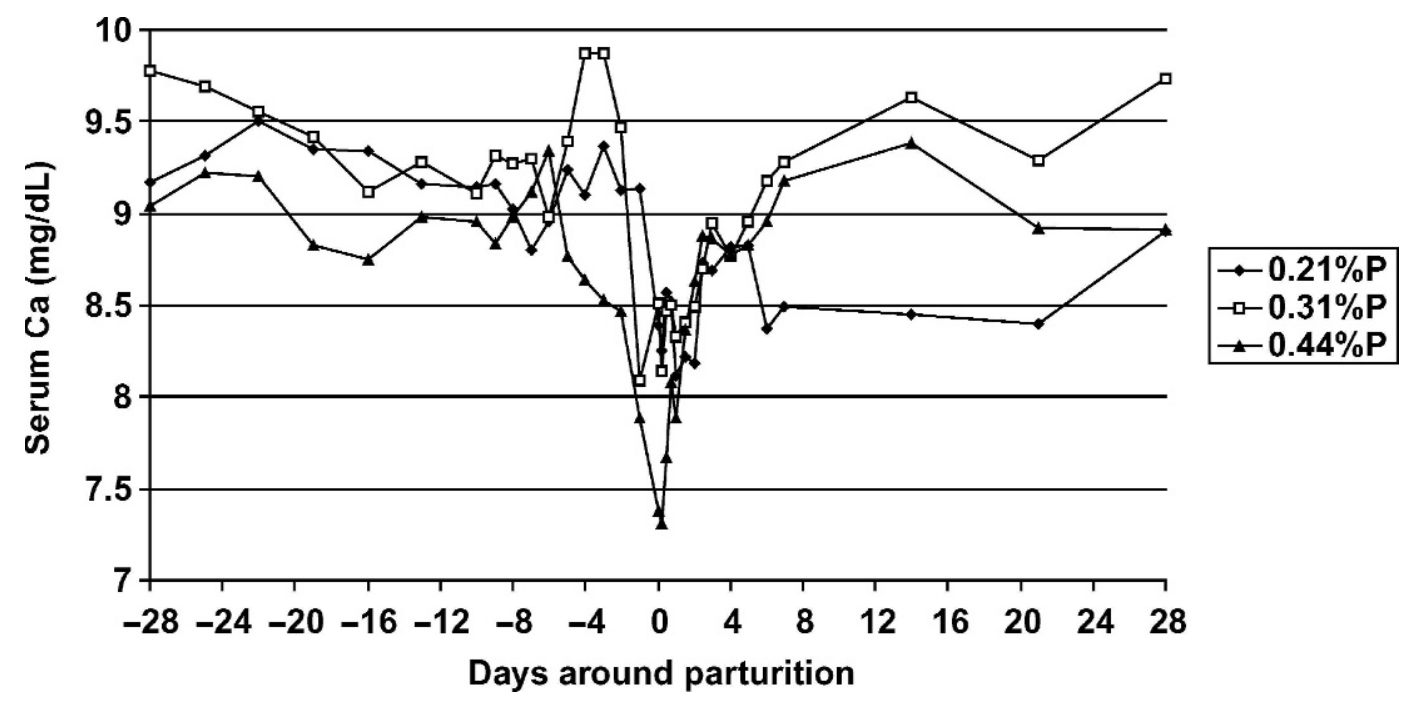

Figure 4. Effects of prepartum dietary $\mathrm{P}$ treatments $(0.21,0.31$, or $0.44 \%$ dietary $\mathrm{P}$, dry basis) on total serum Ca concentrations from $28 \mathrm{~d}$ prepartum through $28 \mathrm{~d}$ postpartum; $\mathrm{d} 0$ is day of calving $(\mathrm{SEM}=0.49 ; P<0.05$ for treatment by time interaction in prepartum period; $P<0.03$ for treatment by time interaction for the periparturient period; $P<0.04$ for treatment by time interaction for the postpartum period). 


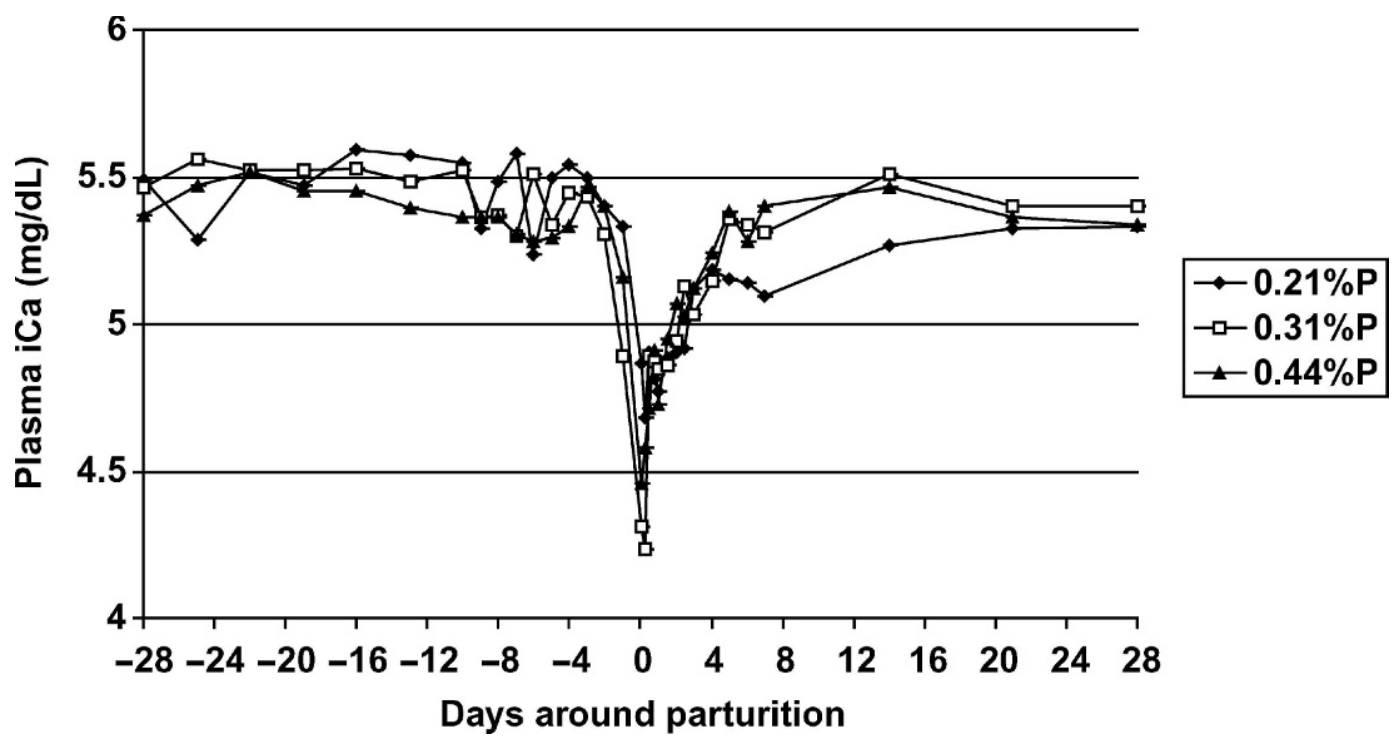

Figure 5. Effects of prepartum dietary $\mathrm{P}$ treatments $(0.21,0.31$, or $0.44 \%$ dietary $\mathrm{P}$, dry basis) on plasma ionized Ca (iCa) concentrations from $28 \mathrm{~d}$ prepartum through $28 \mathrm{~d}$ postpartum; $\mathrm{d} 0$ is day of calving $(\mathrm{SEM}=0.07 ; P<0.01$ for treatment by time interaction in the prepartum period; $P<0.03$ for treatment by time interaction in the periparturient period; $P<0.02$ for treatment by time interaction in the postpartum period).

0.09 nor $0.27 \%$ dietary $\mathrm{P}$ fed to ruminating lambs altered urinary DPD concentrations. Additionally, plasma OHP concentrations were not affected by prepartum dietary $\mathrm{P}$ treatment suggesting no effect on bone resorption activity immediately before parturition $(P>0.10$; Table 4).

\section{Periparturient Period Responses}

In the current experiment, the periparturient period was defined as $7 \mathrm{~d}$ prepartum through $7 \mathrm{~d}$ postpartum. During the period, prepartum dietary $\mathrm{P}$ treatment did not affect DMI $(P>0.10$; Table 5$)$.

Serum P. Blood samples were taken daily $7 \mathrm{~d}$ before calving, immediately after calving $(0 \mathrm{~h}), 6,12,18,24$, $36,48,60,72 \mathrm{~h}$, and 4, 5, 6, 7, 14, 21, and $28 \mathrm{~d}$ after calving. Serum $\mathrm{P}$ concentrations were not influenced by prepartum dietary $\mathrm{P}$ treatment as a main effect $(P$ $>0.10$; Table 5). However, cows in treatment $0.21 \% \mathrm{P}$ had lower serum $\mathrm{P}$ concentrations from $7 \mathrm{~d}$ prepartum through d 0 postpartum, similar concentrations d 1, 2, and 3 , and greater concentrations from 4 through $7 \mathrm{~d}$ postpartum compared with cows fed treatment $0.31 \% \mathrm{P}$ and $0.44 \% \mathrm{P}(0.21 \% \mathrm{P}$ vs. $0.31 \% \mathrm{P}, 0.44 \% \mathrm{P}$ by time, $P<$ 0.01 ; Figure 3). These results are similar to those of Kichura et al. (1982) in which Jersey cows fed $10 \mathrm{~g}$ of $\mathrm{P}$ daily prepartum had lower plasma $\mathrm{P}$ concentrations from $4 \mathrm{~d}$ prepartum until $2 \mathrm{~d}$ postpartum compared with cows fed $80 \mathrm{~g}$ of $\mathrm{P}$ daily. Similarly, Barton et al. (1987) reported that cows fed 0.7 times $P$ maintenance requirement (NRC, 1978) from $28 \mathrm{~d}$ prepartum until parturition had lower plasma $\mathrm{P}$ concentrations from 7 d prepartum until $1 \mathrm{~d}$ postpartum compared with cows fed at 1 or 3 times $\mathrm{P}$ maintenance requirement.

Incidence of hypophosphatemia. Chronic hypophosphatemia is defined as plasma inorganic $\mathrm{P}$ between 2 and $3.5 \mathrm{mg} / \mathrm{dL}$, and acute hypophosphatemia as plasma inorganic P less than $2 \mathrm{mg} / \mathrm{dL}$ (Goff, 1998). By these definitions, incidence rates of chronic hypophosphatemia immediately after parturition ( 0 -h blood sample) were 64,38 , and $25 \%$ for cows in treatment $0.21 \% \mathrm{P}$, $0.31 \% \mathrm{P}$, and $0.44 \% \mathrm{P}$, respectively. Cows in treatment $0.21 \% \mathrm{P}$ had a greater incidence rate of chronic hypophosphatemia than cows in treatment $0.31 \% \mathrm{P}$ and $0.44 \% \mathrm{P}(P<0.04)$. Six hours after parturition, the incidence rates of chronic hypophosphatemia (as defined above) for cows in treatments $0.21 \% \mathrm{P}, 0.31 \% \mathrm{P}$, and $0.44 \% \mathrm{P}$ were 50,15 , and $17 \%$; cows in treatment $0.21 \% \mathrm{P}$ had a greater apparent incidence rate than did cows in treatment $0.31 \% \mathrm{P}$ and $0.44 \% \mathrm{P}(P<0.01)$. Overall, the numbers of cows at $0 \mathrm{~h}$ with serum $\mathrm{P}$ concentrations less than $2 \mathrm{mg} / \mathrm{dL}$ (i.e., acute hypophosphatemia) were 3,1 , and 3 for treatments $0.21 \% \mathrm{P}, 0.31 \% \mathrm{P}$, and $0.44 \% \mathrm{P}$, respectively. Therefore, relatively few cows in each treatment group were actually experiencing acute hypophosphatemia. Neither recumbency nor paresis (clinical hypophosphatemia) associated with the definition of acute hypophosphatemia was observed in this experiment. No cows on this study were treated for clinical hypophosphatemia in the periparturient period and all 
Table 5. Least squares means and orthogonal contrasts for treatment and treatment by time interactions for DM intake and blood variables during the periparturient period ( $7 \mathrm{~d}$ prepartum through $7 \mathrm{~d}$ postpartum).

\begin{tabular}{|c|c|c|c|c|c|c|c|c|}
\hline \multirow[b]{2}{*}{ Variable } & & & & \multirow[b]{2}{*}{$\mathrm{SE}$} & \multicolumn{2}{|c|}{ Contrasts } & \multicolumn{2}{|c|}{ Contrasts by time ${ }^{1}$} \\
\hline & $0.21 \% \mathrm{P}$ & $0.31 \% \mathrm{P}$ & $0.44 \% \mathrm{P}$ & & $\begin{array}{l}0.21 \% \mathrm{P} \text { vs. } \\
0.31 \% \mathrm{P} \\
0.44 \% \mathrm{P}\end{array}$ & $\begin{array}{l}0.31 \% \mathrm{P} \text { vs. } \\
0.44 \% \mathrm{P}\end{array}$ & $\begin{array}{l}0.21 \% \mathrm{P} \text { vs. } \\
0.31 \% \mathrm{P} \\
0.44 \% \mathrm{P}\end{array}$ & $\begin{array}{l}0.31 \% \mathrm{P} \text { vs } \\
0.44 \% \mathrm{P}\end{array}$ \\
\hline & & & & & & & 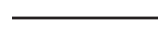 & 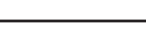 \\
\hline $\mathrm{DMI}, \mathrm{kg} / \mathrm{d}$ & 13.4 & 14.3 & 13.7 & 0.97 & $\mathrm{NS}^{2}$ & NS & NS & NS \\
\hline \multicolumn{9}{|l|}{ Serum minerals } \\
\hline Serum $\mathrm{Mg}, \mathrm{mg} / \mathrm{dL}$ & 1.74 & 1.77 & 1.81 & 0.06 & NS & NS & NS & NS \\
\hline \multicolumn{9}{|l|}{ Plasma variables } \\
\hline Ionized $\mathrm{Ca}, \mathrm{mg} / \mathrm{dL}$ & 5.13 & 5.08 & 5.08 & 0.06 & NS & NS & 0.03 & NS \\
\hline $\mathrm{Na}, \mathrm{mg} / \mathrm{L}$ & 3365 & 3382 & 3366 & 8.30 & NS & NS & NS & NS \\
\hline $\mathrm{K}, \mathrm{mg} / \mathrm{L}$ & 174 & 174 & 173 & 1.90 & NS & NS & 0.04 & NS \\
\hline $\mathrm{Cl}, \mathrm{mg} / \mathrm{L}$ & 3698 & 3680 & 3712 & 19.5 & NS & NS & NS & NS \\
\hline $\mathrm{pH}$ & 7.43 & 7.43 & 7.44 & 0.01 & NS & NS & 0.01 & NS \\
\hline Vitamin $\mathrm{D}_{3},{ }^{3} \mathrm{pg} / \mathrm{mL}$ & 134.7 & 140.8 & 121.7 & 8.15 & NS & NS & NS & NS \\
\hline
\end{tabular}

${ }^{1}$ Interaction of treatment with time for $7 \mathrm{~d}$ prepartum through $7 \mathrm{~d}$ postpartum.

${ }^{2} \mathrm{NS}=$ Not significant $(P>0.10)$.

${ }^{3} \mathrm{BEB}=$ Base excess; $\mathrm{PTH}=$ parathyroid hormone; vitamin $\mathrm{D}_{3}=1,25$-dihydroxyvitamin $\mathrm{D}_{3}\left[1,25(\mathrm{OH})_{2} \mathrm{D}_{3}\right]$.

cows progressed with a normal lactation during the first $28 \mathrm{~d}$.

Serum Ca and Mg. Dietary treatments did not affect mean serum $\mathrm{Ca}$ concentrations from $7 \mathrm{~d}$ prepartum until 7 d postpartum $(P>0.10$; Table 5$)$. However, cows in treatment $0.44 \% \mathrm{P}$ had lower total serum Ca concentrations the last week before calving and during the first $12 \mathrm{~h}$ after parturition compared with cows fed treatment $0.21 \% \mathrm{P}$ and $0.31 \% \mathrm{P}$ (treatment by time interaction; $P<0.03$; Figure 4). Similarly, Kichura et al. (1982) reported that Jersey cows fed $10 \mathrm{~g}$ of $\mathrm{P}$ daily had greater plasma Ca concentrations from $1 \mathrm{~d}$ prepartum through $4 \mathrm{~d}$ postpartum compared with cows fed $80 \mathrm{~g}$ of $\mathrm{P}$ daily. Barton et al. (1987) also reported greater plasma Ca concentrations from 3 to $5 \mathrm{~d}$ postpartum for cows fed 0.7 times $\mathrm{P}$ maintenance requirement (NRC, 1978) compared with cows fed either 1 or 3 times maintenance requirement for dietary P. Greater plasma Ca with lesser prepartum dietary $\mathrm{P}$ could be due to enhanced intestinal absorption of Ca by a vitamin D-mediated transport mechanism (Barton et al., 1987). In the current experiment, periparturient serum $\mathrm{Mg}$ concentrations were unaffected by prepartum dietary $\mathrm{P}$ treatment, which is in agreement with Barton et al. (1987).

Incidence of hypocalcemia. For this experiment, early postpartum ( 0 or $6 \mathrm{~h}$ postpartum) hypocalcemia was defined as either total serum Ca concentrations less than $8 \mathrm{mg} / \mathrm{dL}$ or plasma iCa concentrations less than $4 \mathrm{mg} / \mathrm{dL}$. Cows in treatment $0.21 \% \mathrm{P}, 0.31 \% \mathrm{P}$, and
$0.44 \% \mathrm{P}$ had incidence rates of hypocalcemia (total serum Ca less than $8 \mathrm{mg} / \mathrm{dL}$ ) of 50,69 , and $75 \%$, respectively, with cows in treatment $0.21 \% \mathrm{P}$ tending to have a lower incidence rate than cows in treatment $0.31 \% \mathrm{P}$ or $0.44 \% \mathrm{P}$ at parturition $(P=0.10)$. However, when plasma iCa concentrations were evaluated, dietary treatments did not affect incidence rates of hypocalcemia either at parturition $(0 \mathrm{~h})$ or $6 \mathrm{~h}$ postpartum $(P$ $>0.10$ ). Only one cow, beginning its seventh lactation and fed $0.31 \% \mathrm{P}$ prepartum, exhibited clinical paresis (total serum $\mathrm{Ca}=5.95$ and $6.21 \mathrm{mg}$ of total $\mathrm{Ca} / \mathrm{dL}$ at 0 and $6 \mathrm{~h}$ postpartum, respectively); this cow was treated with Ca-gluconate i.v. after the 6 -h blood sample was drawn and recovered fully. Overall, feeding $0.44 \% \mathrm{P}$ prepartum may increase the incidence of hypocalcemia at parturition when compared with feeding $0.21 \% \mathrm{P}$.

PTH and plasma 1,25 $(\mathrm{OH})_{2} D_{3}$. Prepartum dietary $\mathrm{P}$ treatments did not alter plasma PTH concentrations during the periparturient period. Concentration of PTH averaged $29.3 \pm 3.11 \mathrm{pg} / \mathrm{mL}$ among all cows and specified sampling times (Table 5). The most dramatic rise in PTH relative to calving typically occurs very near calving in response to increasing challenges to Ca homeostasis (Goff et al., 1989). There was a significant time effect pooled across treatments $(P<0.05)$. Concentrations of PTH rose from about $10 \mathrm{pg} / \mathrm{mL}$ (average of all treatments for 5, 3, 2, and $1 \mathrm{~d}$ before calving) to 60 , 90 , and $100 \mathrm{pg} / \mathrm{mL}$ at $0 \mathrm{~h}$ for cows in treatments $0.21 \% \mathrm{P}$, $0.31 \% \mathrm{P}$, and $0.44 \% \mathrm{P}$, respectively. However, no treat- 
Table 6. Least squares means and orthogonal contrasts for treatment and treatment by time interactions for DM intake and blood variables during the postpartum period (from parturition through $28 \mathrm{~d}$ postpartum).

\begin{tabular}{|c|c|c|c|c|c|c|c|c|}
\hline \multirow[b]{2}{*}{ Variables } & & & & \multirow[b]{2}{*}{$\mathrm{SE}$} & \multicolumn{2}{|c|}{ Contrasts } & \multicolumn{2}{|c|}{ Contrasts by time ${ }^{1}$} \\
\hline & $0.21 \% \mathrm{P}$ & $0.31 \% \mathrm{P}$ & $0.44 \% \mathrm{P}$ & & $\begin{array}{l}0.21 \% \mathrm{P} \text { vs. } \\
0.31 \% \mathrm{P} \\
0.44 \% \mathrm{P}\end{array}$ & $\begin{array}{l}0.31 \% \mathrm{P} \text { vs. } \\
0.44 \% \mathrm{P}\end{array}$ & $\begin{array}{l}0.21 \% \mathrm{P} \text { vs. } \\
0.31 \% \mathrm{P} \\
0.44 \% \mathrm{P}\end{array}$ & $\begin{array}{l}0.31 \% \mathrm{P} \text { vs } \\
0.44 \% \mathrm{P}\end{array}$ \\
\hline & & & & & & 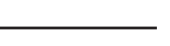 & 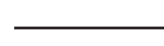 & 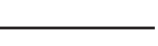 \\
\hline $\mathrm{DMI}, \mathrm{kg} / \mathrm{d}$ & 18.9 & 19.7 & 19.9 & 0.92 & $\mathrm{NS}^{2}$ & $\mathrm{NS}$ & NS & $\mathrm{NS}$ \\
\hline DMI, \% BW & 2.88 & 3.05 & 3.00 & 0.14 & NS & NS & NS & NS \\
\hline BCS change, $\mathrm{kg}$ & -64.0 & -59.0 & -47.0 & 12.4 & NS & NS & NS & NS \\
\hline \multicolumn{9}{|l|}{ Serum minerals } \\
\hline Serum $P, \mathrm{mg} / \mathrm{dL}$ & 6.33 & 6.09 & 6.13 & 0.25 & NS & NS & 0.01 & NS \\
\hline Serum $\mathrm{Ca}, \mathrm{mg} / \mathrm{dL}$ & 8.49 & 8.83 & 8.50 & 0.36 & NS & NS & 0.04 & NS \\
\hline Serum $\mathrm{Mg}, \mathrm{mg} / \mathrm{dL}$ & 1.73 & 1.73 & 1.79 & 0.06 & NS & NS & NS & 0.07 \\
\hline \multicolumn{9}{|l|}{ Plasma variables } \\
\hline $\mathrm{BEB},{ }^{3} \mathrm{mmol} / \mathrm{L}$ & 5.95 & 6.44 & 6.07 & 0.44 & NS & NS & NS & NS \\
\hline $\mathrm{pCO}_{2}, \mathrm{mmHg}$ & 45.8 & 46.7 & 44.5 & 1.01 & NS & NS & NS & 0.01 \\
\hline $\mathrm{HCO}_{3}, \mathrm{mmol} / \mathrm{L}$ & 27.8 & 28.8 & 27.5 & 0.49 & NS & NS & NS & NS \\
\hline Anion gap, $\mathrm{m} M$ & 17.7 & 17.4 & 16.6 & 0.39 & NS & NS & NS & NS \\
\hline \multicolumn{9}{|l|}{ Serum bone markers ${ }^{4}$} \\
\hline Serum OC, ng/mL & 19.7 & 20.9 & 21.4 & 3.18 & NS & NS & NS & 0.04 \\
\hline Serum DPD, ng/mL & 2.96 & 3.00 & 3.56 & 0.30 & NS & NS & NS & NS \\
\hline
\end{tabular}

ment by time interaction was detected $(P>0.10)$. Periparturient plasma $1,25(\mathrm{OH})_{2} \mathrm{D}_{3}$ concentrations averaged $132.4 \pm 8.15 \mathrm{pg} / \mathrm{mL}$ from $5 \mathrm{~d}$ prepartum through $5 \mathrm{~d}$ postpartum and were unaffected by prepartum dietary treatment (Table $5 ; P>0.10$ ).

\section{Postpartum Responses}

Intake, BCS, and BW change. Dry matter intake during the first $28 \mathrm{~d}$ of lactation was not affected by prepartum dietary $\mathrm{P}$ treatment $(P>0.10$; Table 6$)$. Although cows fed treatment $0.21 \% \mathrm{P}$ prepartum tended to have somewhat lower daily DMI in the first $2 \mathrm{wk}$ after calving compared with cows in treatments $0.31 \% \mathrm{P}$ and $0.44 \% \mathrm{P}$ (Figure 1), there was no treatment by time interaction expressed either as absolute daily intake or as a percentage of BW (Table $6 ; P>0.10$ ). There also was no effect of prepartum treatment on BCS or BW change during the first $28 \mathrm{~d}$ of lactation. When different $\mathrm{P}$ concentrations were fed over an entire lactation, similar results were found by Wu et al. $(2000,2001)$ and $\mathrm{Wu}$ and Satter (2000).

Serum P, Ca, and Mg. Prepartum dietary P treatments altered serum $\mathrm{P}$ concentrations over the $28 \mathrm{~d}$ after calving (Table $6 ; P<0.01$ ). Serum $P$ concentrations of cows fed treatments $0.21 \% \mathrm{P}, 0.31 \% \mathrm{P}$, and $0.44 \% \mathrm{P}$ were similar from parturition to $3 \mathrm{~d}$ postpartum, but greater from d 3 to 14 for cows fed treatment $0.21 \% \mathrm{P}$ compared with cows fed treatment $0.31 \% \mathrm{P}$ or $0.44 \% \mathrm{P}$ (treatment $0.21 \% \mathrm{P}$ vs. $0.31 \% \mathrm{P}, 0.44 \% \mathrm{P}$ by day; $P<0.01$; Figure 3). Kichura et al. (1982) reported lower plasma $\mathrm{P}$ concentrations from parturition until $2 \mathrm{~d}$ postpartum when cows were fed $10 \mathrm{~g}$ of $\mathrm{P}$ compared with $80 \mathrm{~g}$ of $\mathrm{P}$ daily from 4 wk prepartum until parturition. However, Barton et al. (1987) reported no effect of varying prepartum dietary $\mathrm{P}$ concentrations on plasma $\mathrm{P}$ concentrations from $1 \mathrm{~d}$ through $7 \mathrm{~d}$ postpartum.

There was no main effect of prepartum dietary treatment on postpartum serum total $\mathrm{Ca}$ concentrations. However, there was a treatment by time interaction (treatment $0.21 \% \mathrm{P}$ vs. $0.31 \% \mathrm{P}, 0.44 \% \mathrm{P}$ by day; $P<0.04$; Table 6; Figure 4). In a previous experiment, prepartum dietary $\mathrm{P}$ concentrations did alter postpartum Ca concentrations from 3 to $5 \mathrm{~d}$ postpartum (Barton et al., 1987). Cows fed 0.7 times maintenance requirement for dietary $\mathrm{P}$ had greater plasma Ca concentrations compared with cows fed at 1 or 3 times maintenance requirement of dietary $\mathrm{P}$. 
Table 7. Least squares means and orthogonal contrasts for milk yield and composition variables during the postpartum period (from parturition through $28 \mathrm{~d}$ of lactation).

\begin{tabular}{|c|c|c|c|c|c|c|}
\hline \multirow[b]{3}{*}{ Milk variables } & & & & \multirow[b]{3}{*}{ SE } & \multicolumn{2}{|c|}{ Contrasts } \\
\hline & \multicolumn{3}{|c|}{ Treatments } & & \multirow{2}{*}{$\begin{array}{l}0.21 \% \mathrm{P} \text { vs. } \\
0.31 \% \mathrm{P} \text {, } \\
0.44 \% \mathrm{P}\end{array}$} & \multirow{2}{*}{$\begin{array}{l}0.31 \% \mathrm{P} \text { vs. } \\
0.44 \% \mathrm{P}\end{array}$} \\
\hline & $0.21 \% \mathrm{P}$ & $0.31 \% \mathrm{P}$ & $0.44 \% \mathrm{P}$ & & & \\
\hline ECM yield ${ }^{1} \mathrm{~kg} / \mathrm{d}$ & 53.4 & 53.2 & 52.2 & 1.49 & $\mathrm{NS}^{2}$ & $\begin{array}{l}P<- \\
\text { NS }\end{array}$ \\
\hline Adjusted ECM ${ }^{3} \mathrm{~kg} / \mathrm{d}$ & 54.4 & 53.2 & 51.7 & 1.58 & NS & NS \\
\hline $\mathrm{SCC}, \times 1000 / \mathrm{mL}$ & 1447 & 592 & 354 & 285 & 0.01 & 0.04 \\
\hline $\mathrm{P}, \mathrm{mg} / \mathrm{dL}$ & 76.9 & 70.6 & 65.5 & 2.25 & 0.01 & 0.06 \\
\hline Fat, \% & 5.44 & 5.32 & 5.04 & 0.23 & NS & NS \\
\hline Fat, $\mathrm{kg} / \mathrm{d}$ & 2.25 & 2.29 & 2.26 & 0.14 & NS & NS \\
\hline Protein, $\%$ & 3.06 & 3.11 & 2.99 & 0.07 & NS & NS \\
\hline Protein, kg/d & 1.23 & 1.29 & 1.30 & 0.05 & NS & NS \\
\hline Lactose, $\%$ & 4.65 & 4.76 & 4.70 & 0.05 & NS & 0.09 \\
\hline Lactose, $\mathrm{kg} / \mathrm{d}$ & 1.89 & 2.00 & 2.04 & 0.18 & NS & NS \\
\hline $\mathrm{SNF}, \%$ & 8.61 & 8.77 & 8.63 & 0.09 & NS & NS \\
\hline $\mathrm{SNF}, \mathrm{kg} / \mathrm{d}$ & 3.49 & 3.67 & 3.75 & 0.14 & NS & NS \\
\hline
\end{tabular}

${ }^{1}$ Energy-corrected milk $(\mathrm{ECM})$ yield $(\mathrm{lb})=0.3246 \times$ milk yield $(\mathrm{lb})+12.86 \times$ fat yield $(\mathrm{lb})+7.04 \times$ protein yield (lb) (Dairy Records Management Systems, 1999).

${ }^{2} \mathrm{NS}=$ Not significant $(P>0.10)$. There were no treatment by time interactions for any variables $(P>0.1)$.

${ }^{3}$ Adjusted ECM = ECM yield using SCC as a covariate in the statistical model.

Serum Mg concentrations were not influenced by dietary prepartum $\mathrm{P}$ treatment (Table 6). Barton et al. (1987) also reported no difference in plasma Mg concentrations from parturition through $7 \mathrm{~d}$ postpartum when cows were fed $0.7,1$, or 3 times maintenance requirement for dietary $\mathrm{P}$.

Plasma mineral elements and acid-base variables. Plasma $\mathrm{iCa}, \mathrm{Na}, \mathrm{K}$, and $\mathrm{Cl}$ concentrations pooled across time and parity did not differ; the numerical differences in these variables among treatments were small (Table 6). There was a treatment by time interaction on postpartum iCa concentrations (treatment $0.21 \% \mathrm{P}$ vs. $0.31 \% \mathrm{P}, 0.44 \% \mathrm{P}$ by day; $P<0.02$; Table 6 ; Figure 5). The general patterns of postpartum relationships among treatments for total serum $\mathrm{Ca}$ and plasma iCa postpartum were similar (Figures 4 and 5). Few treatment effects associated with acid-base status $(\mathrm{pH}$, $\mathrm{BEB}, \mathrm{pCO}_{2}, \mathrm{HCO}_{3}$, and anion gap) were noted in the postpartum period (Table 6 ). There was an interaction of treatment by time on $\mathrm{pCO}_{2}$; the reason for this interaction is not known and its magnitude is relatively small (treatment $0.31 \% \mathrm{P}$ vs. $0.44 \% \mathrm{P}$ by day; $P<0.01$; data not shown).

Serum $O C$ and DPD. There were no significant main effects of prepartum dietary $\mathrm{P}$ treatments on concentrations of $\mathrm{OC}$ in the postpartum period $(P>0.10$; Table 6). This is in contrast to results of Scott et al. (1994) who demonstrated that sheep fed a diet with $0.09 \% \mathrm{P}$ had lower plasma OC concentrations than those fed $0.27 \%$ dietary $\mathrm{P}$; however, their results were not with animals in the early postpartum period. They also were inducing a true and presumably more acute
P deficiency that might be expected to affect bone formation rate. There was a treatment by time interaction on OC concentrations during the postpartum period (samples analyzed on d 0,1,2, 3, and 14 after calving; treatment $0.31 \% \mathrm{P}$ vs. $0.44 \% \mathrm{P}$ by day; $P<0.04$; data not shown); however, the magnitude of differences is small compared with other reports. Corlett and Care (1988) reported that plasma OC concentrations declined by $50 \%$ when sheep were fed $0.04 \%$ dietary $\mathrm{P}$ compared with $0.17 \%$ dietary $\mathrm{P}$ for $1 \mathrm{mo}$. In the current experiment, postpartum serum DPD concentrations were not affected by prepartum treatment and averaged $3.2 \pm 0.30 \mathrm{ng} / \mathrm{mL}$ among cows on all treatments, suggesting no overall influence on bone resorption rate $(P>0.10$; Table 6$)$.

Lactation performance. Average yield of ECM for all cows was $52.9 \mathrm{~kg} / \mathrm{d}$ for the first $28 \mathrm{~d}$ of lactation and was not affected by prepartum dietary $\mathrm{P}$ treatments (Table 7). Milk SCC differed by treatment with cows in treatment $0.21 \% \mathrm{P}$ prepartum averaging greater SCC than cows in treatment $0.31 \% \mathrm{P}$ or $0.44 \% \mathrm{P}(P<0.01$; Table 7). This effect was accounted for by one particular cow in treatment $0.21 \% \mathrm{P}$ whose SCC was very high; its data were kept in all statistical analyses. Additionally, cows in treatment $0.31 \% \mathrm{P}$ had somewhat greater SCC than did cows in treatment $0.44 \% \mathrm{P}(P<0.04$; Table 7$)$. Nonetheless, there was not an apparent relationship between SCC and ECM yield (Table 7). Milk P concentrations during the first month of lactation (weekly milk sampling) were influenced by prepartum dietary $\mathrm{P}$ treatments $(P<0.01$; Table 7$)$, whereas no effect was detected in other studies when dietary $\mathrm{P}$ concentrations 
were varied (Brintrup et al., 1993; Wu et al., 2000, 2001). Concentrations and yields of fat, protein, lactose, and SNF were unaffected by prepartum dietary $\mathrm{P}$ treatment $(P<0.10 ;$ Table 7$)$

\section{CONCLUSIONS}

In this experiment, feeding $34 \mathrm{~g}$ of $\mathrm{P} /$ cow daily $(0.21 \%$ $\mathrm{P}$ in this experiment) during the last $4 \mathrm{wk}$ of gestation was adequate for multiparous Holstein cows. No adverse effects on $\mathrm{P}$ and $\mathrm{Ca}$ metabolism or ECM yield (through 28 DIM) were detected. Feeding $0.44 \% \mathrm{P}$ during the $28 \mathrm{~d}$ prepartum depressed total serum Ca concentrations in the peripartum period compared with feeding either 0.21 or $0.31 \% \mathrm{P}$ and may be of concern if cows are predisposed to hypocalcemia. Although, on average, periparturient serum $P$ of cows in all 3 prepartum treatments was below $4 \mathrm{mg} / \mathrm{dL}$ at the time of calving ( $0 \mathrm{~h}$ sample), no cases of clinical hypophosphatemia were presented and all cows performed normally during the first $28 \mathrm{~d}$ of lactation. It is concluded that the NRC (2001) estimate of the dietary $\mathrm{P}$ requirement for late pregnant multiparous Holstein cows is sufficient for normal metabolic transition from gestation to lactation.

\section{ACKNOWLEDGMENTS}

The authors thank Moorman's Manufacturing Co., Quincy, IL, for providing the biuret, and West Central Soy (Ralston, IA) for providing SoyChlor16-7. Completing statistical analysis of part of the data by T. Pilbeam is acknowledged. The assistance of Kristy Herban in sample collection and analysis is also appreciated.

\section{REFERENCES}

Barton, B. A., N. A. Jorgensen, and H. F. DeLuca. 1987. Impact of prepartum dietary phosphorus intake on calcium homeostasis at parturition. J. Dairy Sci. 70:1186-1191.

Brintrup, R., T. Mooren, U. Meyer, H. Spiekers, and E. Pfeffer. 1993. Effects of two levels of phosphorus intake on performance and faecal phosphorus excretion of dairy cows. J. Anim. Physiol. 69:29-36.

Brommage, R., and H. F. DeLuca. 1985. Regulation of bone mineral loss during lactation. Am. J. Physiol. 248:E182-E187.

Corlett, S. C., and A. D. Care. 1988. The effects of reduced dietary phosphate intake on plasma osteocalcin levels in sheep. Q. J. Exp. Physiol. 73:443-445.

Dairy Records Management Systems. DHI Glossary. 1999. Fact sheet: A-4:9. DRMS, Raleigh, NC.

Daved, D., and H. Struck. 1971. Microliter determination of free hydroxyproline in blood serum. Biochem. Med. 5:17-21.

Fiske, C. H., and Y. Subbarow. 1925. The colorimetric determination of phosphorus. J. Biol. Chem. 66:375-400.
Fukuda, S., and H. Iida. 1993. Histomorphometric changes in iliac trabecular bone during pregnancy and lactation in beagle dogs. J. Vet. Med. Sci. 55:565-569.

Goff, J. P. 1998. Phosphorus Deficiency. Pages 218-220 in Current Veterinary Therapy 4:Food Animal Practice. J. L. Howard and R. A. Smith, ed. W. B. Saunders Co., Philadelphia, PA.

Goff, J. P., T. A. Reinhardt, and R. L. Horst. 1989. Recurring hypocalcemia of bovine parturient paresis is associated with failure to produce 1,25-dihydroxyvitamin D. Endocrinology 125:49-53.

Horst, R. L. 1986. Regulation of calcium and phosphorus homeostasis in the dairy cow. J. Dairy Sci. 69:604-616.

Kichura, T. S., R. L. Horst, D. C. Beitz, and E. T. Littledike. 1982. Relationship between prepartal dietary calcium and phosphorus, vitamin $\mathrm{D}$ metabolism, and parturient paresis in dairy cows. J. Nutr. 112:480-487.

Liesegang, A., R. Eicher, M.-L. Sassi, J. Risteli, M. Kraenzlin, J. L. Riond, and M. Wanner. 2000. Biochemical markers of bone formation and resorption around parturition and during lactation in dairy cows with high and standard milk yields. J. Dairy Sci. 83:1773-1781.

Liesegang, A., M.-L. Sassi, J. Risteli, R. Eicher, M. Wanner, and J.L. Riond. 1998. Comparison of bone resorption markers during hypocalcemia in dairy cows. J. Dairy Sci. 81:2614-2622.

Naito, Y., N. Shindo, R. Sato, and D. Murakami. 1990. Plasma osteocalcin in preparturient and postparturient cows: Correlation with plasma 1,25 dihydroxyvitamin $\mathrm{D}$, calcium, and inorganic phosphorus. J. Dairy Sci. 73:3481-3484.

National Research Council. 1978. Nutrient Requirements of Dairy Cattle. 5th rev. ed. Natl. Acad. Sci., Washington, DC.

National Research Council. 1989. Nutrient Requirements of Dairy Cattle. 6th rev. ed. Natl. Acad. Sci., Washington, DC.

National Research Council. 2001. Nutrient Requirements of Dairy Cattle. 7th rev. ed. Natl. Acad. Sci., Washington, DC.

Reinhardt, T. A., R. L. Horst, J. W. Orf, and B. W. Hollis. 1984 A microassay for 1,25-dihydroxyvitamin $\mathrm{D}$ not requiring high performance liquid chromatography: Application to clinical studies. J. Clin. Endocrinol. Metab. 58:91-98.

Rodriguez-Suarez, L. A. 1998. Periparturient response of cows fed varying dietary cation-anion differences and calcium contents prepartum. Ph.D. Diss., Michigan State Univ., East Lansing.

SAS Institute. 1999. SAS User's Guide. Statistics, Version 8 ed. SAS Inst., Inc., Cary, NC.

Scott, D., S. P. Robins, P. Nicol, X. B. Chen, and W. Buchan. 1994. Effects of low phosphate intake on bone and mineral metabolism and microbial protein synthesis in lambs. Exp. Physiol. 79:183-187.

Valk, H., and L. B. J. Sebek. 1999. Influence of long-term feeding of limited amounts of phosphorus on dry matter intake, milk production, and body weight of dairy cows. J. Dairy Sci. 82:2157-2163.

van Mosel, M., and S. C. Corlett. 1990. Assessment of bone turnover in the dry period of dairy cows by measurement of plasma bone GLA protein, total plasma alkaline phosphatase activity and urinary hydroxyproline. Exp. Physiol. 75:827-837.

Wildman, E. E., G. M. Jones, P. E. Wagner, R. L. Bowman, H. F. Troutt, Jr., and T. N. Lesch. 1982. A dairy cow body condition scoring system and its relationship to select production characteristics. J. Dairy Sci. 65:495-501.

Wu, D., and L. D. Satter. 2000. Milk production and reproductive performance of dairy cows fed two concentrations of phosphorus for two years. J. Dairy Sci. 83:1052-1063.

Wu, Z., L. D. Satter, A. J. Blohowiak, R. H. Stauffacher, and J. H. Wilson. 2001. Milk production, estimated phosphorus excretion, and bone characteristics of dairy cows fed different amounts of phosphorus for two or three years. J. Dairy Sci. 84:1738-1748.

Wu, Z., L. D. Satter, and R. Sojo. 2000. Milk production, reproductive performance, and fecal excretion of phosphorus by dairy cows fed three amounts of phosphorus. J. Dairy Sci. 82:1028-1041. 